\title{
Translation of Intensity in Political Discourse
}

\author{
Iroda Siddikova ${ }^{1} \&$ Nadejda Zubareva ${ }^{2}$ \\ ${ }^{1}$ Professor at the Comparative Linguistics department of the National University of \\ Uzbekistan named after Mirzo Ulugbek; Tashkent, Uzbekistan; Email: i.siddiqova@nuu.uz \\ ${ }^{2} \mathrm{PhD}$ Candidate at the Comparative Linguistics department of the National University of \\ Uzbekistan named after Mirzo Ulugbek; Tashkent, Uzbekistan; Email: \\ zubarevan@yahoo.com; ORCID oooo-ooo1-7895-3301 (Corresponding Author)
}

\begin{abstract}
The political discourse is one of the most dramatic and emotionally expressed types of discourse where intensity could be considered as the means of implementation of pragmatic potential. The preservation of pragmatics of intensifying units as part political discourse while translating them serves to the adequate transformation of the communicative intention of the author and as a result, leads to the achievement of the corresponding communicative effect in the target language. This paper examines ways of translating intensification in the political discourse. Three types of methods for implementing intensification in translation have been discussed: (1) the explicit expression of intensification, (2) the creation of intensity in translation, and (3) the reduction in the intensity of expressions. The results of the study show that not every equivalent translation is recognized as adequate, but only one that meets, in addition to the norm of equivalence, other regulatory requirements.
\end{abstract}

Keywords: Intensification, Political Discourse, Translation, Communication

\section{Introduction}

Political discourse is the phenomena which we observe in our everyday life. The more open and democratic life of society, the more attention is paid to the language of politics (Chudinov 2006). The high level of manipulation of human consciousness is a characteristic feature of the way of communication in political discourse.

Political communication is a speech activity focused on the propaganda of certain ideas, the emotional impact on the citizens of the country, and their incitement to political actions. It helps to develop social harmony, adopt and justify socio-political decisions in the face of multiple points of view in the society.

Political discourse, like other types of discourse, has two dimensions: real and virtual. The real dimension is understood as the current speech activity in a certain social space, as well as the texts resulting from this activity, obtained by the interaction of linguistic, paralinguistic, and extralinguistic factors. The virtual dimension of discourse is a semiotic space, including verbal and non-verbal signs, oriented towards servicing the sphere of political communication, a thesaurus of precedent statements, a set of models of speech actions, and genre-specific to communication in this field.

The language of politics refers to the terminology and rhetoric of political activity, where politicians act in their professional role (like the discourses of other professional fields). The

(C) AesthetixMS 2020. This Open Access article is published under a Creative Commons Attribution Non-Commercial 4.o International License (http://creativecommons.org/licenses/by-nc/4.o/), which permits non-commercial re-use, distribution, and reproduction in any medium, provided the original work is properly cited. For citation use the DOI. For commercial re-use, please contact editor@rupkatha.com. 
specifics of professional languages, including the language of politics, lies in the vocabulary designed to nominate referents for a particular subject area of activity.

Since power as a psychological phenomenon includes irrational and emotional levels, communication on political topics is never neutral or objective, it is characterized by evaluative emphasis, partiality, and intensity.

Political speech and texts are well-planned actions, demanding long and meticulous preparation as politicians not only aspire to inform the audience about some aspect of public life but also to reach the audience and to convince the listener to take this or that position and to gain the support of the citizens (Malina 2011). Nowadays, the success of a politician depends on his ability to master mechanisms of political communication. Political discourse aims to influence (Sheygal 2000). The system of binary opposition is the basis of political language. The dual system is a necessary condition of democratic society: the system of pro and con argumentation, agree and criticize. One of the elements of such a dual system is intensity too. The important characteristic instrument of political speech is the intensification of some facts, positions.

Political communication makes an impact on the political, economic, and social development of the country as well as the improvement of its democratic institutions and the effectiveness of foreign affairs, stability in the society depends on its quality. The mechanisms and tools of political communication are under the attention of prominent academics. All mentioned supports the relevance of the study of intensification in political discourse according to the way of cognition and its leverage of communicative strategies.

While translating texts of political discourse the translation of intensifying units of language is one of the ways of implementation of the suggestive function.

\section{Category of Intensification}

An integral attribute of an intensification is the degree scale. A characteristic property of the degree scale is a sign of growth. The degree scale is dynamic, it unfolds in two directions: the directions of increasing and decreasing the amount of this trait. There are zones of intensification and deintensification on the degree scale between which there is a zone of neutral (Fig.1).

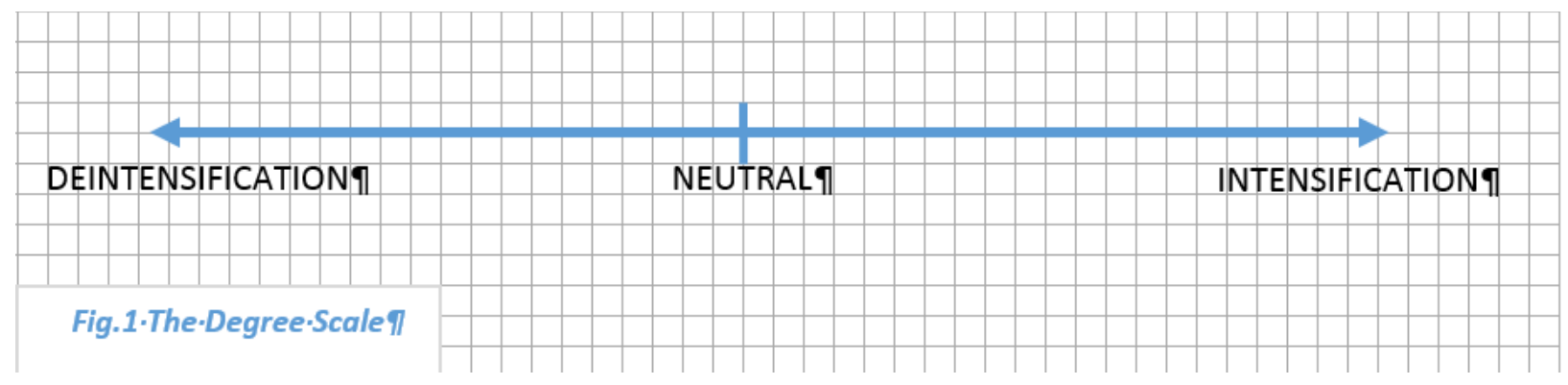

Being an onomastic category, the intensity is related to the connotative level of language and speech. Intensification could be applied not only to the attribute of a certain object or phenomenon, but also the attitude towards it (Rodionova 2004).

This fact is of particular importance when intensification is used for socially significant purposes, such as political discourse. The attitude of the politician or journalist to the presented phenomenon, explicitly or implicitly expressed, is of great importance for the effectiveness of persuasive speech, since the political discourse by its nature is aimed at instilling certain views and opinions to the potential addressee. 
The use of various expressive means which express the value of the degree of attributes in combination with the attitude to this phenomenon entails the intensification of the communicative effect.

There is a significant difference in views on such problems as the boundaries of the category of intensity. Modern interpretations of the given concept point out the relationship of the category of intensity with quantitativeness and qualitativeness, the interaction of intensity with the categories of expressiveness, emotionality, evaluativeness, and imagery.

The broadest definition of the category of intensity includes such a range of phenomena as a change in the degree of an attribute to any side (increase or decrease), the size of an object, the strength of an action, etc. The category of intensity includes a wide range of linguistic phenomena, all the differences both in the degree of the attribute, and in size, value, etc.

A more specific interpretation of the category of intensity includes only a change in the attribute or quantity in the direction of its increase from the neutral point on the conceptual scale of graduality. The pragmatic aspect is the most important indicator for the category of intensity as the subjective significance for participants in the situation of this increase in the quantity of attribute. (Rodionova 2004).

Many researchers recognize the intensity as the qualitative-quantitative category. So, according to E.I. Sheigal, the category of intensity is at the intersection of the categories of quantity (indefinite, non-discrete quantity) and quality that can be quantified (Sheygal 1990).

Intensity is realized at all language levels by various means. The most studied and the most widely used means are intensifiers (very, absolutely, extremely) and intensifiers - words that implicitly contain this intensity (bad - ugly).

Thus, various means of expressing the degree of intensity contribute to the allocation of individual elements by increasing or decreasing the value of certain ideas, views, assessments, and play a significant role in political discourse.

\section{Translation of the intensifying vocabulary}

The translation of the intensifying vocabulary used by politicians in their speeches is a certain difficulty, since the result of its pragmatics are often far-reaching and no longer linguistic problems. Besides, it can lead to undesirable socio-political consequences. The success criterion for the translated political text is determined by how effectively the language means of influence are used in the translation, and how the translated text meets the norms of mass communication accepted in the target language group. Any translation that focuses only on the content of a sociopolitical text and ignores the need to ensure its pragmatic value cannot be recognized as adequate. In other words, the politician who makes the speech creates a certain communicative effect that must be correctly conveyed during the translation. At the same time, intensifying vocabulary plays one of the important roles, since it is the main tool for expressing a person's degree of attitude to a particular object, event, or phenomenon.

We investigated various ways of implementing the intensification vocabulary in translation, as well as translation transformations, with the help of which it is possible to convey the meaning of utterance correctly. The text of modern political speeches and articles of journalists in English, Russian, and Uzbek languages have been used as material for the study, where the language units containing an intensifying component have been selected. Methods for implementing intensification in translation include the explicit expression of intensification, the 
creation of intensity in translation, and the reduction in the intensity of expressions. We would like to consider these methods with specific examples.

\section{Case Study 1}

International Handicrafts Festival was held in Kokand, Uzbekistan in September, 2019. On September 14, 2019, the President of the Republic of Uzbekistan Sh. Mirziyoyev sincerely congratulated the participants and expressed gratitude to foreign guests for their attention and respect for the country, for this event. His speech was in Uzbek with simultaneous translation into English. Later, we observe the following translations in government sources and analyzed them.

In the mentioned above speech, we found the following words.

Shu o'rinda buyuk mutafakkir Bahouddin Naqshband bobomizning "Hunar shunday tulporki, unga mingan kishi albatta hurmat-e'tibor topgay va saodat manziliga yetgay", degan hikmatli so'zlarini eslab o'tishni joiz, deb bilaman. (Prezident.uz/oz 2019).

The utterance 'saodat manziliga yetgay' literally stands for 'to reach the destination of bliss' (Butayev, 2013). The expression in the Uzbek language conveys expressive meaning. It is figurative.

In English, the observed example sounds in the following way.

In this regard, I believe it will be noteworthy to recall a wise saying uttered by outstanding thinker Bakhauddin Nakshband whose 7ooth anniversary we shall celebrate next year: "Crafts is as if a fairytale ambler, on its wings a man can reach the highest horizons both the recognition and respect of the people" (MFA.uz/en 2019).

The expressive utterance in Uzbek was translated into English with the help of intensification on a morphological level 'to reach the highest horizons'.

In Russian we found:

В связи с этим, думаю, будет уместным вспомнить мудрое изречение выдающегося мыслителя Бахоуддина Накшбанда, 7оо-летие которого мы отметим в будущем году: "Ремесло - словно сказочный иноходец, на его крыльях человек может достичь самых высоких рубежей - признания и уважения народа” (MFA.uz/ru 2019).

The counterpart of the discussed utterance in Russian represented by intensification on the lexical level too. It is also having the same literal translation as the English 'to reach the highest horizons'.

Therefore, in the analyzed case we observed the creation of intensity in translation as in English so in Russian languages. The semantic fields of English and Russian are coinciding in the given examples but differ from Uzbek counterpart.

\section{Case Study 2}

The following quotation also refers to the speech of the President of the Republic of Uzbekistan Sh. Mirziyoyev in International Handicrafts Festival in September, 2019 in Kokand.

... kabi yurtdoshlarimiz mamlakatimizning 'eng oliy mukofoti' - O'zbekiston Qahramoni unvoniga sazovor bo'lgani ushbu soha vakillarining sharafli mehnatiga yuksak e'tibor ifodasidir. (Prezident.uz/oz 2019). 
According to Butayev, 'eng' stands for 'the very', 'the most'; 'oliy' means 'superior', 'higher', 'supreme'; 'mukofot' could be translated as 'reward', 'award'. In other words, 'eng oliy mukofoti' denotes 'the highest award' in the given context. By adding 'eng' the author of the speech underlined and stressed the rank of the award. The authors of the speech subjective value of the given increase of attribute's quantity is the main condition for intensification to appear. So the given utterance is intensifying in its core.

Let's have a look into English translation of the given part of the delivered speech.

... were well noted by awarding them a high rank of the Hero of Uzbekistan. This serves as a bright confirmation of profound attention being paid to the representatives of this sphere. (MFA.uz/en 2019).

In the English counterpart, the supreme degree cannot be observed as in Uzbek. The same was found in Russian translation.

... отмечены высоким званием Героя Узбекистана, что является ярким потверждением большого внимания, уделяемого представителям этой сферы (MFA.uz/ru 2019).

Russian 'высоким званием' totally coincide with English 'a high rank' in the mentioned context. But still, we could not find a translation of intensifying Uzbek 'eng' in both cases. Therefore, the reduction in the intensity of expression is stated in the given example.

\section{Case Study 3}

Nowadays, the main agenda worldwide is pandemic, which is a challenge for the whole of humanity. During the extraordinary summit meeting of the Turkic Council on April 10, 2020, the President of the Republic of Uzbekistan underlined it too.

$\mathrm{Bu}$ pandemiya, o'zining ko'lami va miqyosiga ko'ra, mislsiz global inqirozga, butun bashariyat taqdiri va jahon iqtisodiyoti uchun g'oyat jiddiy sinovga aylandi (Prezident.uz/oz 2020).

'G'oyat' stands for 'extraordinary', 'very', 'extremely'. Consequently, the utterance is intensive. In the English translation the intensification of the expression was observed too.

The pandemic that we all have encountered has grown into an unprecedented global crisis in terms of the pace and scale of its contagion and has become a very serious challenge for the entire human race and the global economy (Prezident.uz/en 2020).

As well as in Russian we found intensification in this utterance.

Пандемия, с которой мы все столкнулись, по своим темпам и масштабам распространения переросла в беспрецедентный глобальный кризис, стала очень серьёзным вызовом для всего человечества и мировой экономики (Prezident.uz/ru 2020).

The explicit expression of intensification observed in the source Uzbek language as well as in both target languages English and Russian in the last case.

\section{Conclusion}

There are various types of translation, with the main problem being its adequacy and equivalence. Some scientists understand equivalence as preserving the relative equality of sense-bearing, informative, semantic, stylistic, as well as functional-communicative information, which is 
contained in the target language to the same extent as in the original. The equivalence of the original and the translated text is a common understanding of the information contained in the source text, including the message that affects not only the mind, but also the feelings of the recipient, which is not only explicitly expressed in the text, but also implicitly related to the subtext.

The choice of speech means that behavior which is adequate to a particular communicative situation and tactics of speech depends on the personality of each specific communicator. The personal characteristics of communicants, both explicit and hidden, are actualized in the process of their speech activity. Therefore, the effectiveness of communication largely depends on both taking into account the personal characteristics of a particular communicant and his belonging to a particular culture.

The main determining principle of text equivalence is a communicative-functional attribute, which incorporates the equality of the communicative effect produced on recipients of translated and original texts. However, such a perception may not be the same due to different personal, cultural, social reasons.

An equivalent translation reproduces the contents of the original at one of the levels of equivalence. In turn, an adequate translation reproduces the contents and forms of the original employing another language. We agree with the opinion of V. Komissarov, that any adequate translation must be equivalent (at one or another level of equivalence), but not every equivalent translation is recognized as adequate, but only one that meets, in addition to the norm of equivalence, other regulatory requirements.

Therefore, in the given study we observed that adequate translation of intensity in political speech could be reached by the following three tactics: the explicit expression of intensification; the creation of intensity in translation; and the reduction in the intensity of expressions.

Significant difficulties are represented by the translation of expressive language units, which are represented by figurative, emotionally saturated utterances, bright national character. As a rule, mentioned units have ambiguity, which makes its translation difficult. Consequently, very often expressive units of Uzbek language translated with the help of the creation of intensity in the target language as depicted in Case Study 1.

The difficulty is not only the translation, but also the recognition of intensity in the text. Separation and lack of relation (for a non-native speaker) between the context and the components of the intensification complicate the translation process. The structure of English, Uzbek and Russian languages are different and from a genetic point of view they belong to different language families and finally, they represent different language pictures of the world.

This research proves that adequate translation of intensity plays an important role in realizing the pragmatic potential of a political discourse and in helping the interpreter to achieve desired communicative intentions.

\section{References}

Abramyan S.A. (2016). Angloyazychnyy politicheskiy diskurs v mezhkul'turnom kontekste. -Yer., Izd-vo YEGU. - 534 s. 
Alefirenko N.F. (2014). Kognitivno-pragmaticheskaja subparadigma nauki o jazyke. Kognitivnopragmaticheskie vektory sovremennogo jazykoznanija: sb. nauch. tr. M. 16-27. (In Russ.).

Anderwald, L. (2016). I'm loving it-Marketing ploy or language change in progress? Studia Neophilologica. https ://doi.org/10.108o/o0393 274.2016.1208536.

Bagga- Gupta, Sangeeta. (2014). Languaging: Ways- of- being- with- words across Disciplinary Boundaries and Empirical Sites. In Language Contacts at the Crossroads of Disciplines, ed. Heli Paulasto, Lea Meriläinen, Helka Riionheimo, and Maria Kok, 89-130. Newcastle- upon- Tyne: Cambridge Scholars Publishing.

Bagga- Gupta, Sangeeta. (2018). Learning Languaging Matters. Contributions to a Turn- on- Turn Reflexivity. In Reconceptulizing Conceptions between Language, Learning and Literacy, ed. Sangeeta Bagga- Gupta, Anne Golden, Lars Holm, Helle Laursen, and Anne Pitkänen- Huhta. Rotterdam: Springer.

Baker, M. (2010). In Other Words, (London: Routledge).

Bali, Aasita and Jagan, Shivani. (2017). Use of Social Media in India and Political Communication. International Journal of Humanities and Social Science Studies IJHSSS, 243-253. http://oaji.net/articles/2017/1115-1486537686.pdf.

Balli SH. (1961) Frantsuzskaya stilistika. M., s. 202

Bell R.T. (1991). Translation and Translating: Theory and Practice, (London: Longman).

Berlizon S.B. (1972). Virajeniye ekspressivnosti i emocionalnosti v frazeologicheskih edinicah i slove. Voprosi frazeologii. Trudi Sam.GU im. Navoi, novaya seriya. Vip.219. Samarkand. 242. (In Russ.).

Butayev Sh. (2013). English-Uzbek dictionary: 80.ooo words and expressions = Inglizchao'zbekcha lug'at : 8o.ooo so'z va ibora. Toshkent : O'qituvchi.

Chomsky, Noam. (2003). Power and terror, (New York : Seven Stories).

Chudinov A. P. (2006). Politicheskaya lingvistika. M.: Flinta: Nauka. 254 S

Jacobsen, N. (2015). A Cognitive Linguistic Analysis of English Conditionals in English for Special Purposes (EAP) Instruction: Implications from Sociocultural Theory. In K. Masuda, C. Arnett, \& A. Labarca (Eds.), Cognitive Linguistics and Sociocultural Theory, 103-126. Berlin: Mouton de Gruyter.

Johansson F.M. \& Gibbs, R. W. (2012). Embodied Motivations for Metaphorical Meanings. Cognitive Linguistics, 23, 251-272.

Johansson M. (2006). Constructing objects of discourse in the broadcast political interview. Journal of Pragmatics, 38 (2), 216-229. https://doi.org/10.1016/j.pragma.2005.06.016.

Levinson, S. (1983). Pragmatics. Cambridge: Cambridge University Press.

Macmillan Dictionary. (2020). https://www.macmillandictionary.com/

Malina A. D.(2011). Politicheskaya ritorika: Lingvisticheskiye strategii argumentirovannogo diskursa v sovremennom angliyskom yazyke (na mat. publichnykh vystupleniy) [Elektronnyy resurs]. URL: http://rae.ru/forum2011/18/1582

Merriam-webster (2020). Dictionary. https://www.merriamwebster.com/dictionary/at\%20a\%2osnail\%27s\%2opace. 
MFA.uz/en (2019). Official web-site of the Ministry of Foreign Affairs of the Republic of Uzbekistan (in English). https://mfa.uz/en/press/news/2019/o9/20965/.

MFA.uz/ru (2019). Ofitsial'nyy veb-sayt Ministerstva inostrannykh del Respubliki Uzbekistan (in Russian). https://mfa.uz/ru/press/news/2019/o9/20964/

Nowak, E., \& Michaelson, E. (2019a). Meta-metasemantics, or the quest for the one true metasemantics. (Manuscript).

Ornatowski, C.M. (2012). "The Idea of Politics in 'Political' Rhetoric" Forum Artis Rhetoricae, 2/2012, 7-21.

Prezident.uz/en (2020). Official website of the President of Uzbekistan (in English). https://president.uz/en/lists/view/3494

Prezident.uz/oz (2019). O’zbekiston Respublikasi Prezidentining Rasmiy Veb-sayti. (in Uzbek). https://president.uz/oz/lists/view/2863.

Prezident.uz/oz (2020). O'zbekiston Respublikasi Prezidentining Rasmiy Veb-sayti. (in Uzbek). https://president.uz/oz/lists/view/3494).

Prezident.uz/ru (2020). Ofitsial'nyy veb-sayt Prezidenta Respubliki Uzbekistan (in Russian). https://president.uz/ru/lists/view/3494).

Radionova S.Ye. (2004). Intensivnost' i yeyo mesto v ryadu drugikh semanticheskikh kategoriy. Slavyanskiy vestnik. 2. M. MAKS Press. 303-308. (In Russ.).

Rodionova, S.Ye. (2004). Intensivnost' i yeye mesto v ryadu drugikh semanticheskikh kategoriy [Tekst] / S.Ye. Rodionova // Slavyanskiy vestnik. - Vyp. 2. - M.: MAKS Press.

Rosch, Eleanor. (1975). Cognitive representations of semantic categories. Journal of Experimental Psychology: General 104 (3): 192-233.

Runciman D (2007) The paradox of political representation. J Polit Philos 15(1):93-114

Sapir, E. (1949). Selected Writings in Language, Culture and Personality. LosAngeles: University of California Press.

Schäffner, C. (1997). "Strategies of Translating Political Texts”, in Text Typology and Translation, Anna Trosborg (ed), (John Benjamins). 119-145.

Schäffner, C. and Bassnett, S. (2010). Political discourse, media and translation. Newcastle : Cambridge Scholars.

Sheygal Ye. I. (2000). Semiotika politicheskogo diskursa: diss. ... d. filol. n. Volgograd. 431 s.

Sheygal, Ye.I. (1990). Intensivnost' kak komponent semantiki slova v sovremennom angliyskom yazyke [Tekst]: diss. ... kand. filol. nauk / Ye.I. Sheygal. - M.

Speaks, J. (2016). Speaker and hearer in the character of demonstratives. Mind, 125(498), 301-399.

Stojni'c, U., Stone, M., \& Lepore, E. (2017). Discourse and logical form: Pronouns, attention, and coherence. Linguistics and Philosophy, 40(5), 519-547.

Stone J, Fernandez N (2008) To practice what we preach: the use of hypocrisy and cognitive dissonance to motivate behavior change. Soc Personal Psychol Compass 2(2):1024-1051

Turanskiy I.I. (1990). Semanticheskaya kategoriya intensivnosti v angliyskom yazyke. Monografiya. M.: Vysshaya shkola.173. (In Russ.). 
9 | Translation of Intensity in Political Discourse

Turanskiy I.I. (1991). Soderjaniye i virajeniye intensivnosti v angliyskom yazike. Dis...dok.filol.nauk. M. 6-7. (In Russ.).

Wierzbicka, Anna. (1991). Cross-cultural pragmatics: the semantics of human interaction.NewYork:de Gruyter.

Zheng, Tongtao. (2000). Characteristics of Australian Political Language. Rhetoric:Tactics of gaining public support and shirking responsibility. 